\title{
Moral and Ethical Education in the Kyrgyz Society in Late XIX to Early XX Centuries
}

\author{
Samara Osmonova1, Uulkan Tilekova1, Aida Duishonbaeva², \\ Ainura Kydykeeva3 ${ }^{3}$, Zhypargul Abdullaeva ${ }^{*}$ (1)

\footnotetext{
${ }^{1}$ Department of Kyrgyzstan History, Archeology and Ethnology, Osh State University, Osh, Kyrgyzstan

${ }^{2}$ Department of General history and Teaching Methods, Osh State University, Osh, Kyrgyzstan

${ }^{3}$ Department of Interfaculty Russian Language, Osh State University, Osh, Kyrgyzstan

${ }^{4}$ Science and Research Department, Osh State University, Osh, Kyrgyzstan

Email: jypar.science@oshsu.kg
}

How to cite this paper: Osmonova, S., Tilekova, U., Duishonbaeva, A., Kydykeeva, A., \& Abdullaeva, Z. (2021). Moral and Ethical Education in the Kyrgyz Society in Late XIX to Early XX Centuries. Advances in Applied Sociology, 11, 99-111. https://doi.org/10.4236/aasoci.2021.112008

Received: January 31, 2021

Accepted: February 16, 2021

Published: February 19, 2021

Copyright $\odot 2021$ by author(s) and Scientific Research Publishing Inc. This work is licensed under the Creative Commons Attribution International License (CC BY 4.0).

http://creativecommons.org/licenses/by/4.0/

(c) (i) Open Access

\begin{abstract}
This article is considering moral and ethical education in the Kyrgyz Society from late XIX to early XX centuries. The relevance of research focused on moral values, which are closely relate to other aspects of culture, including important basis for many ideas, actions and relationships in society. Respectful and caring attitude toward elder people and children, the desire to help those who need moral and material aid, mercy in its various manifestations, help and mutual assistance in relation to neighbors with relatives, the concept of honor, duty and responsibility, fulfillment of certain obligations assumed as the basis of the Kyrgyz people moral culture. Research objectives include study of moral and aesthetic education problems in the Kyrgyz family, comprehensive study of the culture and life of the region, to reveal the mechanisms of transferring ethno-cultural traditions in the process of raising the children. Moral and ethical educations are multifaceted processes. This article discusses just a few aspects of this important and complex problem. Practical significance in this work is formation of the theoretical provisions and conclusions creating preconditions for implementation of the ethno-cultural orientation in modern education. The results of this study enrich theory and practice of educating the current generation with new factual knowledge, expanding the scientific understanding of the unity of the social and ethnic in the content and organization of the educational process.
\end{abstract}

\section{Keywords}

Morality, Ethics Education, Tradition, Culture, Family, Social Environment 


\section{Introduction}

Cultural heritage has always served and serves as the basis for spiritual development of generations. Heritage categorized into natural and cultural types; comprises physical artifacts or hypothetical practices, group, community activities and attributes along the time (Keitsch, 2019). Heritage ethics established from a set of concerns based on the cultural materials and standards of professional practice to a contemporary focus on human rights and conserved as a legacy of the past for future generations (Álvarez-García et al., 2019).

The cultural heritage contains and concentrates humanistic values that are not subject to senescence. The world's cultural wealth accumulated over the millennia owing to the works and creativity of different people must and has an enduring cultural, historical, moral and aesthetic significance. Cultural wealth definition formed jointly with empirical evidence on the relationship between cultural heritage and insubstantial cultural elements (Capello et al., 2020). The same situation attributed to the cultural heritage of the Kyrgyzs. In Kyrgyzstan many historical and archaeological sites, representing periods from the Stone Age onwards, that contribute to the country's heritage are existing (Tabaldiev, 2014). Research problem is the study of moral and aesthetic education in the Kyrgyz family, the culture and life of region, and ethno cultural traditions in the children education. Research objects in this work are moral and ethical education on the example of Southern Fergana people experiences.

In history, the "time connecting thread" is never discontinued, because of which the world cultural heritage capital gradually accumulates, which is passed down from generation to generation. As researchers noted, "history is a sequential change of generations, each of which takes from the past: materials, capital, productive forces that were created by previous generations; because of this, generation continues the inherited activity under completely new conditions, and modifies the old conditions through completely changed activities. In our opinion, all this words about the essence of the objective law on historical continuity of culture including morality as its component. It is known that each generation uses the accumulated experience, assimilates achievements and moves forward towards the creation of new cultural values. Research contributed to establishment of systemic, interactive, complex, and social-critical vision of heritage and heritage education, thus providing basis for the relationship between citizenship and construction of identity (Gómez-Carrasco et al., 2020). Role of cultural heritage in the history class is shown in Table 1 describing statistics in questionnaire based on the Student $\mathrm{t}$-test (Student $\mathrm{t}$-test $=0.29 ; p>$ 0.05 ; Student t-test $=0.26 ; p>0.05$ ), on the example of Spain and England; Figure 1 showing rating of item "Local and traditional fiestas" as a resource for teaching History: (a) Spain; (b) England (Gómez-Carrasco et al., 2020).

However, the poverty of the spiritual world, primitiveness of requests, narrow outlook are often accompanied by disrespect to history, a desire to erase the memory of the past as something outdated. It is known that the historical cultural 
Table 1. Descriptive statistics of cultural heritage items in the history class (Gómez-Carrasco et al., 2020).

\begin{tabular}{ccccccc}
\hline & $\begin{array}{c}\text { N } \\
\text { Spain }\end{array}$ & $\begin{array}{c}\text { Mean } \\
\text { Spain }\end{array}$ & $\begin{array}{c}\text { SD } \\
\text { Spain }\end{array}$ & $\begin{array}{c}\text { N } \\
\text { England }\end{array}$ & $\begin{array}{c}\text { Mean } \\
\text { England }\end{array}$ & $\begin{array}{c}\text { SD } \\
\text { England }\end{array}$ \\
\hline Textbook & 343 & 2.97 & 1.042 & 162 & 3.39 & 0.986 \\
Internet & 343 & 3.78 & 0.895 & 162 & 3.63 & 0.958 \\
Documentary sources & 343 & 4.23 & 0.815 & 162 & 4.59 & 0.596 \\
Press & 343 & 3.90 & 0.915 & 162 & 3.62 & 0.892 \\
Teachers notes & 343 & 3.70 & 0.952 & 162 & 3.53 & 0.879 \\
Museums & 343 & 4.31 & 0.822 & 162 & 4.23 & 0.733 \\
Cinema & 343 & 3.96 & 0.894 & 162 & 3.42 & 1.014 \\
Historical novel & 343 & 3.28 & 1.100 & 162 & 3.11 & 1.028 \\
Local and traditional \\
fiestas
\end{tabular}
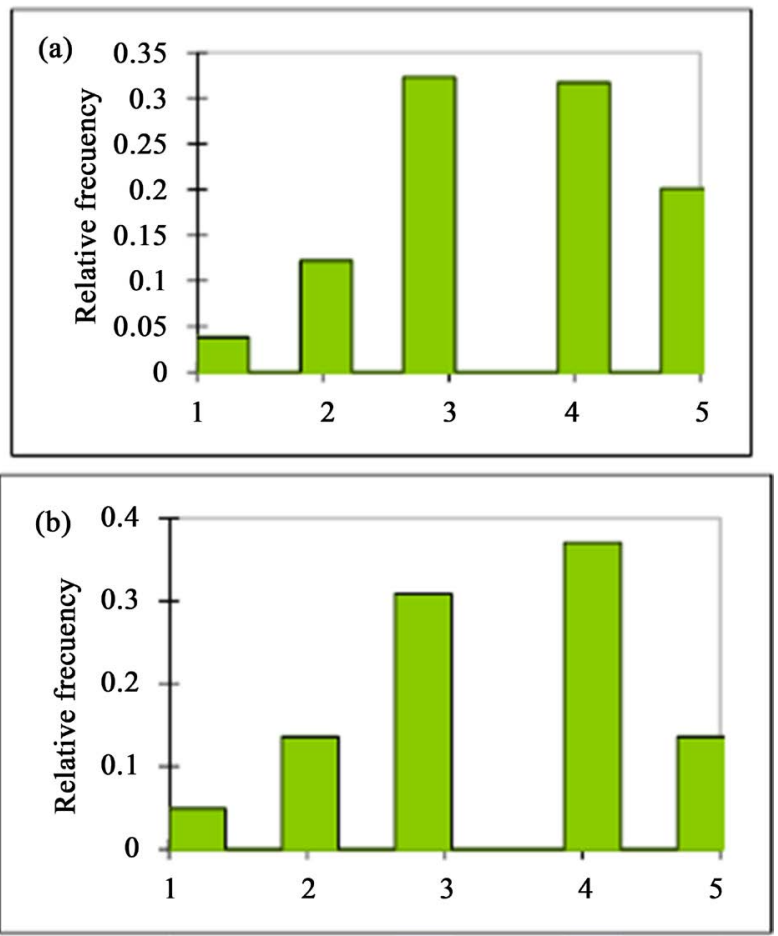

Figure 1. Example rating of item "Local and traditional fiestas" as a resource for teaching History: (a) Spain; (b) England (Gómez-Carrasco et al., 2020).

environment surrounds a person from childhood, in it he gains moral strength, learns dignity and nobility, joins the history of his people, city, village, etc. The cultural environment becomes an integral part of his life, a source of memories of events and meetings, a necessary condition for the emergence of a sense of spiritual "settledness", attachment to different places, to some extent the life-giving basis of patriotism and love for the native land. If a person is not interested in the history of his nation, and history of his own family, does not value family 
heirlooms, is not proud of his home, does not know the history of his city, street, family, maybe something has been missed in childhood, and his patriotic feelings with moral traits will not be strong in him.

Social significance of this research is an essential ethical culture as obligatory moment for any social system of "human production", which constitutes of social production, social and family life. "The production of human" is made up not only of the physical production of human individuals, but also from material, spiritual and aesthetic conditions of their life and of the personality itself. The latter, in contrast to "child production", can be called "processing of people by people", which has its own stages, aspects and directions. The material interpretation explains that a person is formed and develops as a subject of labor, production and political relations, as a personality of a particular historical epoch, as a unique individuality, taken in a social aspect in this process. However, one cannot underestimate the place given to the moral formation of the individual. A person cannot be formed only physically. When there is a talk about someone who has formed as a person, first, it means the persons high moral qualities. Exactly, the moral and ethical education is providing human social stability and his relationship within society, more than any other sphere of a person's inner world, as it is considered as a public social right that everyone should have access (Kromydas, 2017).

Moral and ethical education in the Kyrgyz society was conducted by traditional educational institutions such as the maktab and madrasa until the 1930s (Shadymanova \& Amsler, 2018). Maktab was located near mosque, often in the teachers house, where he and his wife looked after boys and girls separately, while madrassa was a college where adults, who already received their primary education in mosques or private schools (Mirbabaev et al., 2020). During the $20^{\text {th }}$ century, government-supported primary schools have tended to supplant the maktab in Muslim countries (Editors of Encyclopaedia Britannica, 2007).

Although numerous internal and external initiatives have sought to reshape Kyrgyzstan's curriculum and instructional strategies, these projects have paid little attention to moral education and its role in educational reform for democracy (Misco \& Hamot, 2007).

\section{Research Methods}

Literature analysis and review based on the moral and ethical education in the Kyrgyz Society from late XIX to early XX centuries. Materials obtained and collected during field research works conducted in Batken region during the year 2014. Results and discussions based on the research methods, mainly the methodological basis of this work that was made up by a comparative analysis of materials and principles of history on the problem under consideration. The study based on a systemic approach in the study of the system of traditional education, in particular related to morality and ethics, on the complex application of methods of structural, stationary, functional, historical and comparative analyses. In addition, while working on this study, the following methodological 
works were carried out: analysis of ethnographic materials on traditional moral and ethical education; survey and interviews-interviews with senior informants; comparative analysis to determine general and special aspects in the traditional upbringing of Kyrgyz children.

\section{Results and Discussions}

Following the researcher B. Apysh, upbringing of a true Kyrgyzs perfect personality required a thoughtful use of a set of means for all-round influence, the choice of more effective means of influencing the personality by popular teachers (Apysh, 2008). According to the scientist opinion, the most effective tools influencing children's consciousness and feelings were epics, puzzles, proverbs, songs, tales, and folklore.

The purpose of the epics and puzzles as developing mental education, proverbs and songs are developing moral and aesthetic education. One of the important tasks was to educate the correct perception of socially significant values. Because of this, the Kyrgyzs harshly condemned idleness, a consumer attitude towards public opinion, which was of great importance in their culture. Another task or, more precisely, the precept of upbringing considers the necessity to build fundamentals for directed behavior already in childhood. The main task of humankind is morality; good or bad person is formed not during birth, but in education said Kyrgyz people. The most important commandments were considered: "do not lie", "do not steal", "do not offend your neighbor", which were assimilated by Kyrgyz children along with their mother's milk.

The basis of the culture of any people is the national character, which is a significant component of national psychology, and without taking this and many other factors into account, it is impossible to consider the household, economic and political life and control the main directions of the life and activities of any people.

The Kyrgyzs paid great attention to the moral education of the younger generation. With the generally accepted norms of morality, initially, the rules of behavior obtained by child in the family, where the main role played by the elders behavior as an example. Growing up children gradually entered the system of relationships that existed in the family, and it became for them as immutable law of relationships between elders and younger ones, rules of behavior in relation to relatives, neighbors, etc.

The traditional norms of behavior passed down from generation to generation were practically related to all aspects of the social life in society: from birth and marriage to work, everyday communication in family life and work, public forms of leisure, etc. As a rule, they were not regulated by any specific legal institutions, but they were sometimes more stronger than the latter, based in their essence on public morality and public opinion.

\section{Moral Norms and Behavior Development}

The entire set of moral and aesthetic norms of behavior of any people is built on 
the views of these people about a certain positive image of the "ideal representative" of their society at a certain time, in a certain setting and in a certain role. And this collective, historically formed image of an "ideal", "mythologized person" of this or other ethnic community is, as it were, forever imprinted in the minds of each member of this community. Moral norms are considering as a subgroup of social norms in which they explicitly govern behaviors with positive or negative outcomes (FeldmanHall et al., 2018). In addition, moral and ethical aspects of leadership are becoming an important point in society, influencing education, healthcare, economy and other sections (Bao \& Li, 2019) of behavior historically develops and existing inherently in each nation and the norms of national etiquette instruct a member of this community to follow a given standard in each specific situation. All this together can be called as "rules of good tone". Essentially, in different peoples, same as among the Kyrgyz people, this standard is somewhat different, stemming from the way of life, the prevailing way of life, moral and ethical ideas, concepts of attitude towards the opposite sex, older and younger, towards each other, about kind and evil, good and bad, courage, heroism, honesty, their antipodes, etc.

As it is known, any nation has formed historically, as it were, written and unwritten norms of "deserving behavior", nonobservance of which is condemned by other members of society. Despite the fact that the violation of the norms of such "ideal behavior" or "ideal model" of behavior was not directly legally punished or punished, they nevertheless persisted and exist for long periods of time in a particular ethnic community, being interdependent elements of a social, ethnic and confessional nature.

In the Kyrgyz family, in the educational process, the priority was traditionally given to the upbringing of such moral qualities as honesty, truthfulness, modesty, politeness, respect for parents, for elders, and hospitality.

Simplicity, dignity, sociability, loyalty to relatives and friends were considered pronounced traits of the character of the Kyrgyz people. Great importance was attached to the development of highly moral relations and their daily observance. An old Kyrgyz proverb says: "Adamdyn korku-adep, Adamdyn korku-adilettuulukto, zhigittin korku-adeptuulukto, Adeptuu kishi-azaptan alys," which means, "Morality adorns a person", "Justice decorates a man" which is far from disaster." So what is "Adep-ahlak", it is considered as an etiquette, norms of behavior, ethics and aesthetics. "Adep-ahlak" is a whole complex, or system of ethical norms. The Kyrgyz, being in the past a long time an unwritten people, have created an interesting, deeply and subtly thought-out system of unwritten moral norms of behavior concerning almost all aspects of life and activities that characterize complex relationships in the family, in everyday life, in society and even at the government leaders level. "Adep-ahlak" means morality, which is defined as a set of etiquette rules of behavior concerning the external manifestation of attitudes towards people socialization (Stokhof, 2018), dealing with others, forms of treatment, greetings, behavior in public places, demeanor, 
dress, etc. Etiquette is an integral part of the "external culture of society", culture of behavior.

The behavior culture, behavior norms, and etiquette are the parts of world culture (D'Angelo, 2020). It is known that the Kyrgyz have never lived in isolation, without communication with other peoples. Since ancient times, the Kyrgyz have communicated not only with their closest neighbors Uzbeks, Kazakhs, Tajiks, but also with other close and distant peoples. These connections were evidenced by archaeological sites, written sources, folklore and field ethnographic materials. Fundamentals of the world culture development such as mutual enrichment, mutual influence and interchange also should be noted. It is also known that in such cases any people, including the Kyrgyzs, perceive and bring into their culture basically what is close to them in psychology and way of life.

\section{Moral and Esthetic Education Importance}

Moral and aesthetic education can be considered as an important, essential basis for the formation of character, moral and ethical appearance of a person throughout his life, his relationship with society; it largely determines the real status of a person in the social environment. Students' aesthetic knowledge and experiences are expressed in judgements, further elaborated, and mainly concerned with cognitive aspects based on conceptual understanding (Caiman \& Jakobson, 2019). Consequently, moral and ethical education is important in the development of students' aesthetical, beauty, and moral judgment skills (Cui et al., 2019). Kyrgyzs paid much attention to the upbringing of such moral categories in children as discipline, a sense of collectivism, obedience and respect for parents and elders, loyalty in friendship, love for the homeland, etc. In boys, the courage, faithfulness, perseverance, and self-assertion were educated; and in girls, patience, politeness, obedience to elders and to her future husband were educated. All of this was corresponded to the ideal of moral and aesthetic perfection of that period, when the criteria for the upbringing the younger generation among the Kyrgyzs were closely related to the historical conditions of their life. One of the important and main postulates of moral education were: the development and consolidation of such qualities in children as respect for elders, for parents, for persons of the opposite sex, a sense of duty and honor, honesty, modesty, self-esteem, etc. An important requirement was that children should grow up ashamed of their wrong actions, that they should be conscientious "namystuu".

At the time we are observing, the Kyrgyzs raised their children on the Islam moral values, and tried to pass on to them the corresponding economic and crafting skills. Knowledge in general was very highly valued, and any opportunity to teach or learn something was never missed (Apysh \& Kozukulov, 2005). Adults and older family members were responsible for younger ones, instilling in them skills that could be useful in life. The analysis of our field materials makes it possible to say, that the children learned traditions of respectful attitude 
towards parents, relatives, elders and guests in their daily communication. It is noteworthy that young children were usually very attached to the older family members (grandmothers, grandfathers, aunts, etc.). One of the informants told us that in the old days "small children and 70 - 80 year olds went out and sat down where it was convenient for them in the yard. At the same time, the elders conducted peaceful conversations with each other, while not letting the playing children out of sight". Our informant recalled how he enjoyed listening to stories, tales of grandfather Kalcha, who had the talent of a storyteller and a connoisseur of children's souls (Osmonova, 2014).

The Kyrgyzs, due to happening historical processes, have lost a lot of cultural values along with their "original writing", which we know only from folk legends. We imagine that Kyrgyz linguistic layer has also undergone a lot of changes, as it has changed with each new upheaval of the social structure. The new life made its own adjustments, imposed its own ideology. Nevertheless, deeply and subtly thought-out systems of moral norms concerning all aspects of people's life and activities have been preserved in the treasuries of national memory.

These norms characterized complex relationships in the family, everyday life, and in the society. They are like centuries-old giant towers, silently standing, keep in their greatness the beauty and love of their contemporaries and our ancestors who created them, and it seems they say with dignity: "Not the deaf and dumb people built us, but your proud multifaceted ancestors. They knew how to write, read, and count, and speak the languages of their neighbors, and be friends, and trade with the world. "The system of social relations that has developed in the life of the older generation has developed spiritually, at the same time changing and improving it.

A lot of people were included in the contours of social relations created by the past development, acquiring the spiritual qualities programmed in them, improving them in different spheres of life; after leaving life, they leave for new generations the higher level of moral development of personality. Regardless of how long the system of social relations retains its contours and how sharply the new system differs from the old one, the process of succession of generations is never interrupted. It is well known that a necessary condition for social progress is precisely the continuity of generations, which exists in all areas of life: production-political, economic, in the field of legal, moral, aesthetic, social relations.

One of the methods in moral education of children in a Kyrgyz family was the encouragement for good deeds, which was supposed to contribute to the development of positive traits in the behavior of children and awakening their desire to behave with dignity. Often in upbringing, praise was used, an expression of satisfaction with certain actions of children. For the good behavior of the child in the presence of other children, they praised him, set him up as an example. An effective form of encouraging children was considered approval of their actions not only by their parents, but also by neighbors and acquaintances. Ac- 
cording to our field data, the most effective form of encouragement for children was the approval of their actions from father.

\section{Family, Children and Household Relation Characteristics}

Since ancient times, the characteristic features of the family and household relations of Kyrgyz people are the deep reverence by children of their parents, respect for elders, noble behavior towards people around them, regardless of their nationality, gender, education, position in society, etc. The custom encouraged respect for the elderly. Moral experience involves feelings of indignation, confusion, contentment, and emotional responses that can be made to the object of moral thinking under influence of emotion on learning and memory (Tyng et al., 2017).

The elder person spoke first in all cases, the young man gave up his seat and stood, served food, listened to his advice, etc. It was considered extremely indecent to interfere in the conversation of elder people, to laugh loudly in their presence, to say what is indecent for sex and age, to commit any ignorant act in the presence of elders, including in the presence of parents.

Elementary skills were gradually taught to children: skills of addressing adults, behavior during a meal, at guests, at a party, etc. The Kyrgyzs, especially women, were calm and affectionate in the family, never spoke in a raised voice and did not apply harsh punishments to children. Children were taught to follow instructions, advice, requests from parents and elders. According to custom, it was supposed: if a boy sent by his parents on business met an old man on the street and he asked him to do something, then this request was fulfilled first, and then the instructions of the parents.

If, when meeting each other, the younger rode on a horse, and the older followed on foot, the younger had to dismount, go to the older and offer him his horse. From an early age, children were taught the idea that they were indebted to their mother, to their parents. "There is no obligation higher than the obligation to the mother," says a Kyrgyz proverb. If a teenager saw that a woman was chopping wood, carrying a heavy load, then he had to help her, regardless of whether she was a relative to him or not. Kyrgyz children really consider themselves to be indebted to their parents, especially to their mother. It should be noted that this idea has been persistently introduced into the minds of young people over the centuries by the older generation, reinforcing it with a number of institutions and customs that were dictated by necessity in conditions when society did not materially provide old age, when parents could rely only on their children and saw in them the only support and breadwinner in old age.

Therefore, raising children in infancy to maturity did not exclude violence against their will and consciousness. The first, i.e. the elderly were entitled to honor and respect, while the duty of the young was obedience to the elders. It follows from what has been said that the Kyrgyzs have always paid great attention to fostering respectful attitude towards elders in the younger generation. 
(Abramzon, 1999). The generally accepted norms of morality and the rules of behavior of the child were introduced primarily in the family. The main role in this, as it was said, was played by the behavior of elders, their example. The beginning of this upbringing system was the family, its microenvironment, first of all, the affectionate attitude of the mother towards her children. To characterize this, we present some folklore works. For example, a parting song:

I wish you a long life good health!

Let the pastures be filled with cattle,

And the stockroom is filled with seeds.

Let your yard be filled with cattle,

And the house is filled with children

I wish you long life! (Osmonova, 2014)

This is one of the main desires for child, which is necessary in his life.

Children in a Kyrgyz family were, and still are, treated with great attention, affection, care and love. Children, especially the youngest, were often indulged. Etiquette and ethics of Kyrgyzs prescribed to treat children gently, patiently, with restraint. They tried not to shout at the children, they were not angry at them. All family members strove to instill in children from an early age good nature, kindness, respect and respect for elders, women, and a kind attitude towards all living things. The emotional tone of the parents' attitude towards their children gradually changed as the child grew older: from gentle forgiveness in early childhood to demanding strictness in adolescence and friendly care in youth.

From childhood, a special attitude was brought up to the mother. In no case could she be offended by even bad thoughts, you could not be rude to her, raise your voice to her, the main thing in relation to the mother is love, caring for her. In the traditional culture of the Kyrgyzs, motherhood has always been the central concept of a woman's destiny, and traditional rituals formed immutable laws, according to which a girl's childhood was only a preparation for motherhood. In some families, a woman had to patiently endure grievances from her husband and his other relatives in order to keep the family together for the sake of the children. Children in all their affairs consulted with their father and received his blessing: "Allaga amanat, Qudai saktasyn" which means, "God help, God save".

And only in very rare cases, the father resorted to the power of the curse. According to the Kyrgyz, the curse of the father was extremely effective. The Kyrgyz said "ata kargyshy-ok", which means, "Damnation of father is bullet". A man who deserved damnation of his father expected severe disasters and misfortune for himself. The one cursed by his parents became an outcast, and everyone looked at him as if he was outcasted. Popular morality and the norms of behavior based on it demanded unconditional respect for parents throughout their lives. Children were obliged to obey their parents in everything, and also to 
support them in old age.

Respect for old age is not just a sign of respect for his years, for marital status if she is a grandmother or grandfather. This is respect for their store of knowledge, life experience, all that they saw, heard, carried with dignity through the years and hardships; these are the songs they have heard; life seen; rituals in which they took part; these are the hands that spun, embroidered, caressed grandchildren, baked; they warmly welcomed and hugged the guests. "Sadaga bolup ketein, baleketindi alayin", these expressions do not have a literal translation into Russian language, but expressing female sacrifice and willingness to give their strength and life for a child (either for own child, or for grandchildren), which means, "So that I take your troubles on my own, so that I die for you." Religious and moral basis of intergenerational relationships in the family was especially clearly manifested in the popular idea of the meaning of parental blessing and parental curse.

Research findings based on summing up what has been said about moral and ethical education. It was noted that the Kyrgyz people follow etiquette, the behavior rules at home, at social and in public places. There was a certain order of veneration for the elders. The etiquette in the Kyrgyz people society provided for everything: speech, vocabulary, posture of the speaker and much more. According to etiquette, the younger had to always greet the elder, in addition, show all signs of attention. Moral culture in its own way is a continuous process of transforming existing moral requirements into the inner world of a person.

The study of folk ethics makes it possible to highlight some of its aspects, the practical appeal to which is especially necessary in modern conditions. Based on enduring moral values and long-term collective experience, ethical standards have been adapted to the way of life of the Kyrgyz. Morality, to a greater extent than any other sphere of the inner world of a person, ensured his social stability, his connection with society.

It was considered correct ethical if the son followed the precepts of his father: disobedient children were considered ungrateful and punishment for parents from God. Etiquette attitudes changed and continued their life, by adapting to new conditions. Politeness, accuracy, obedience, self-control, tolerance, benevolence, the desire to be pleasant, and respectful attitude towards the elderly were highly valued in the past and largely determine the principles of social behavior of the Kyrgyz today. Respect and reverence for elders, as well as subordination in social and family relations by age, sex, and social status are some of the important principles. This was manifested in all aspects of verbal and non-verbal communicative behavior in the rituals of meeting, addressing and greeting, in the rules for receiving and meeting guests, in serving meal, conducting a conversation, gestures, postures, etc.

\section{Conclusion}

The Kyrgyzs consider that high moral qualities were ordained to people by God. 
It was considered correct and ethical, if son followed the precepts of his father; naughty children were viewed as ungrateful and were a punishment for their parents. "Abiir tapsa balasy, atasyna bak konot" means "If the son is conscientious, then the father is happy". Even the etiquette with moral attitudes has changed, they are adapting to new conditions, and continuing their existence. It is known that Muslim culture is syncretic by its nature: difficult economic conditions, lack of land, not always equal relations with neighbors, and much more gave rise to the manifestation of temperament. And to a large extent, the entire system of moral education was aimed to moderate it.

The culture in modern society is characterized by a complex of cultural and everyday norms of etiquette, designed to practically solve moral problems, which are an essential part of the society culture. It is still important for the Kyrgyz people to know and observe the established rules of daily behavior, served as an example of parents, elders, and others to acquire their norms, rules related to moral and ethical education in the Kyrgyz Society same as in late XIX to early XX centuries. The Kyrgyz people believed that God prescribed high moral and ethical qualities, and main task of a person was to follow these prescriptions.

\section{Conflicts of Interest}

The authors declare no conflicts of interest regarding the publication of this paper.

\section{References}

Abramzon, S. M. (1999). Selected Works on the History of Kyrgyzs and Kyrgyzstan (896 p.). Bishkek: Kyrgyzstan-Soros Foundation.

Álvarez-García, M. E., \& de la Cruz del Río-Rama, C. Á. (2019). Cultural Heritage and Tourism Basis for Regional Development: Mapping of Scientific Coverage. Sustainability, 11, 6034. https://doi.org/10.3390/su11216034

Apysh, B. T. (2008). Educational Process (230 p). Bishkek: Osh.

Apysh, B., \& Kozukulov, T. (2005). The Wise Thoughts of the Prophet Muhammad on Education (99 p.). Osh: Osh State University.

Bao, Y. J., \& Li, C. P. (2019). From Moral Leadership to Positive Work Behaviors: The Mediating Roles of Value Congruence and Leader-Member Exchange. Frontiers of Business Research in China, 13, Article No. 6.

https://doi.org/10.1186/s11782-019-0052-3

Editors of Encyclopaedia Britannica (2007). Maktab.

https://www.britannica.com/topic/maktab

Caiman, C., \& Jakobson, B. (2019). The Role of Art Practice in Elementary School Science. Science \& Education, 28, 153-175.

https://doi.org/10.1007/s11191-019-00036-2

Capello, R., Cerisola, S., \& Perucca, G. (2020). Cultural Heritage, Creativity, and Local Development: A Scientific Research Program. In S. Della Torre, S. Cattaneo, C. Lenzi, A. Zanelli (Ed.), Regeneration of the Built Environment from a Circular Economy Perspective (pp. 11-19). Cham: Springer.

https://doi.org/10.1007/978-3-030-33256-3 2 
Cui, X., Cheng, Q., Lin, W., Lin, J., \& Mo, L. (2019). Different Influences of Facial Attractiveness on Judgments of Moral Beauty and Moral Goodness. Scientific Reports, 9, Article No. 12152. https://doi.org/10.1038/s41598-019-48649-5

D’Angelo, M. (2020). International Business Etiquette From Around the World. https://www.business.com/articles/so-international-business-etiquette-from-around-th e-world/

FeldmanHall, O., Son, J. Y., \& Heffner, J. (2018). Norms and the Flexibility of Moral Action. Personality Neuroscience, 1, e15. https://doi.org/10.1017/pen.2018.13

Gómez-Carrasco, C. J., Miralles-Martinez, P., Fontal, O., \& Ibañez-Etxeberria, A. (2020). Cultural Heritage and Methodological Approaches-An Analysis through Initial Training of History Teachers (Spain-England). Sustainability, 12, 933. https://doi.org/10.3390/su12030933

Keitsch, M. M. (2019). Heritage, Conservation, and Development. In W. Leal Filho, A. Azul, L. Brandli, P. Özuyar, \& T. Wall (Eds.), Sustainable Cities and Communities. Encyclopedia of the UN Sustainable Development Goals (982 p.). Cham: Springer. https://doi.org/10.1007/978-3-319-71061-7 5-1

Kromydas, T. (2017). Rethinking Higher Education and Its Relationship with Social Inequalities: Past Knowledge, Present State and Future Potential. Palgrave Communications, 3, Article No. 1. https://doi.org/10.1057/s41599-017-0001-8

Mirbabaev, A. K., Zieme, P., \& Furen, W. (2020). The Development of Education: Maktab, Madrasa, Science and Pedagogy.

https://en.unesco.org/silkroad/knowledge-bank/development-education-maktab-madr asa-science-and-pedagogy

Misco, T., \& Hamot, G. I. (2007).Post-Soviet Moral Education: The Case of Kyrgyzstan. International Education, 36, 48-69.

Osmonova, S. (2014). Field Materials. Batken Region: Author notes.

Shadymanova, J. \& Amsler, S. (2018) Institutional Strategies of Higher Education Reform in Post-Soviet Kyrgyzstan: Differentiating to Survive Between State and Market. In J. Huisman, A. Smolentseva, \& I. Froumin (Eds.), 25 Years of Transformations of Higher Education Systems in Post-Soviet Countries. Palgrave Studies in Global Higher Education (pp. 229-257). Cham: Palgrave Macmillan. https://doi.org/10.1007/978-3-319-52980-6 9

Stokhof, M. J. B. (2018). Ethics and Morality, Principles and Practice. Zeitschrift für Ethik und Moralphilosophie, 1, 291-304. https://doi.org/10.1007/s42048-018-0016-x

Tabaldiev, K. (2014). Kyrgyzstan: Saving Archaeological Sites. In C. Smith (Eds.), Encyclopedia of Global Archaeology (8015 p.). New York, NY: Springer. https://doi.org/10.1007/978-1-4419-0465-2 1195

Tyng, C. M., Amin, H. U., Saad, M. N. M., \& Malik, A. S. (2017). The Influences of Emotion on Learning and Memory. Frontiers in Psychology, 8, 1454.

https://doi.org/10.3389/fpsyg.2017.01454 